\title{
A Putative Transcription Factor with Seven Zinc-Finger Motifs Identified in the Developing Suprachiasmatic Nucleus by the Differential Display PCR Method
}

\author{
Yoshiro Maebayashi,, ${ }^{1,2}$ Yasufumi Shigeyoshi,, ${ }^{1}$ Toru Takumi, ${ }^{1}$ and Hitoshi Okamura1 \\ ${ }^{1}$ Department of Anatomy and Brain Science, Kobe University School of Medicine, Kobe 650-0017, Japan, and \\ 2Department of Psychiatry, Kyoto Prefectural University of Medicine, Kyoto 602-8566, Japan
}

\begin{abstract}
The suprachiasmatic nucleus (SCN) is a mammalian central circadian pacemaker. This nucleus develops in the last stage of fetal life and matures to make strong synaptic connections within 2 weeks of postnatal life to establish strong oscillation characteristics. To identify factors that initiate the circadian oscillation, we applied a differential display PCR method to developing SCN, and isolated a gene with seven zinc-finger motifs, Lot1, which encodes a gene that appeared at a very high level in the SCN during the early postnatal days. Lot1 mRNA first appeared at postnatal day 1 (P1) at a very high level, and the signal in the SCN continued to be very high until P10 and thereafter rapidly decreased until P20 and was expressed
\end{abstract}

at a very faint level during adulthood. Lot1 mRNA expression was observed only in neurons of the dorsomedial SCN throughout the course of development. During the developmental stage, Lot1 mRNA expression shows a circadian rhythm with a peak in the day time and a trough at night time in both lightdark and constant dark conditions. These observations imply that Lot1 is the first identified putative transcription factor expressed only in the period of active synaptogenesis in the SCN, where Lot1 might play a role in establishing autonomous oscillation.

Key words: suprachiasmatic nucleus; Lot1; development; $m R N A$ differential display; zinc finger; in situ hybridization
In mammals, the hypothalamic suprachiasmatic nucleus ( $\mathrm{SCN}$ ) is a central circadian pacemaker that regulates numerous behavioral and physiological rhythms (Moore, 1973). Recent molecular studies have established a number of putative "clock genes" in mammals, including mPer1, mPer2, mPer3, Clock, BMAL1, and mTim (Dunlap, 1999). Unexpectedly, these genes are expressed not only in SCN but also in other brain areas and in peripheral organs, suggesting that the molecular machinery for the rhythmic oscillatory molecules exists in most cells. However, in mammals, it is already established that the oscillating activity of behavior and endocrine rhythms is governed solely by the SCN; among all the organs, the SCN is the only nucleus showing strong autonomous electrophysiological and metabolic activity (Inouye and Kawamura, 1979). Thus, there might be a mechanism unique to the SCN that produces high oscillatory activity.

The SCN is equipped with a pacemaker (composed of thousands of SCN cells) and efferent pathways. To the pacemaker, optic nerve innervates directly or indirectly as its entraining pathway. The pacemaking components are generated and equipped for a long developmental period. In rats, the neurogenesis of the SCN is completed by embryonic day 18 (E18) (Ifft, 1972; Altman and Bayer, 1978), and just after, SCN begin to oscillate (Reppert and Schwartz, 1984), the process of which is

Received June 14, 1999; revised Aug. 27, 1999; accepted Sept. 8, 1999.

This work was supported in part by grants from the Special Coordination Funds of the Science and Technology Agency of Japan, the Grant-in-Aid for the Scientific Research on Priority Areas of the Ministry of Education, Science, Sports and Culture of Japan, the Ministry of Welfare, the Mitsubishi Foundation, and SRF. We thank Prof. K. Fukui (Kyoto Prefectural University of Medicine) for encouragement.

Correspondence should be addressed to Dr. Hitoshi Okamura, Department of Anatomy and Brain Science, Kobe University School of Medicine, 7-5-1 Kusunokicho, Chuo-ku, Kobe 650-0017, Japan. E-mail: okamurah@kobe-u.ac.jp.

Copyright (C) 1999 Society for Neuroscience $0270-6474 / 99 / 1910176-08 \$ 05.00 / 0$ entrained by the maternal circadian system (Weaver and Reppert, 1989). After birth, there is no light entrainment of circadian rhythm in the first week, and entrainment is established at 2-3 weeks (Moore, 1991). Neuronal activity is weak in the perinatal period and gradually increases to the adult level at 1-3 weeks (Shibata and Moore, 1988). Phenotypic change in neurotransmitters also occur during the first 2 weeks. We previously demonstrated phenotypic change in vasoactive intestinal peptide (VIP)expressing neurons from postnatal day 10 (P10) to P20 in the SCN (Ban et al., 1997). These studies suggest that SCN acquires the characteristics of high oscillatory amplitude after the several sequential steps of development. Coupling of each oscillatory cell might be an important factor for the $\mathrm{SCN}$ to be the robust oscillator. To find molecules that are key to making the SCN oscillatory machinery robust, in the present study we applied a differential mRNA display method, which is based on RT-PCR (Liang and Pardee, 1992; Inokuchi et al., 1996a), to the developing SCN. From the SCN just after neurogenesis, we isolated cDNA encoding a putative transcription factor, Lot1 [previously isolated in rat ovarian surface cell lines that are expressed only in the nontransforming state: lost on transformation 1 (Abdollahi et al., 1997)], which is a zinc-finger protein of the ZAC/LOT family important for apoptosis and cell cycle arrest (Spengler et al., 1997; Varrault et al., 1998; Pagotto et al., 1999). Furthermore, we characterized its expression characteristics at the developmental stage in relation to the maturation of the SCN.

\section{MATERIALS AND METHODS}

Animals

Pregnant female Wistar rats (Nihon Animal Care, Osaka, Japan) were obtained at 7-10 d of gestation (timed pregnancy). They were maintained in individual cages under standard laboratory conditions with diurnal lighting (LD; lights on at 6 A.M. and off at 6 P.M.), with free access to 
food and water. These rats typically give birth on the 22nd day after mating. The day after the mating was designated as E1. To study the fetuses, pregnant females were anesthetized deeply with ether, and the fetuses were removed and perfused. The fetuses were anesthetized by deep low-temperature anesthesia. The time of birth was carefully noted, and the day after the birth was designated as P1. All postnatal animals were anesthetized with ether before they were killed. We used fetuses of both sexes but only male postnatal rats.

For the developmental in situ hybridization histochemical study, we used E18 $(n=4)$ as well as E20 $(n=4), \mathrm{P} 1(n=4), \mathrm{P} 3(n=4), \mathrm{P} 5(n=$ 4), P7 $(n=4), \mathrm{P} 10(n=6), \mathrm{P} 20(n=4)$, and P50 (adult; $n=5)$ animals.

The daily rhythm of the Lot1 mRNA signals was analyzed in P10 rat SCN. Animals were adapted to LD conditions for 2 weeks, including the embryonic period. At P8, half of these rats $(n=42)$ were transferred to constant darkness (DD), and the other rats $(n=42)$ remained in LD conditions. In these experiments, circadian time (CT) 0 and CT12 are referred to as 6 A.M. and 6 P.M., respectively. At P10, rats in LD were killed at Zeitgeber time (ZT) 0 ( 0 was designed as the transition time from the dark to light phase), 4 ( $4 \mathrm{hr}$ after the onset of the light phase), $8,12,16$, and 20 . The other rats were killed on the second day in DD, and the time point was at CT0, 4 (4 hr after the onset of the second subjective day), $8,12,16$ ( $4 \mathrm{hr}$ after the onset of the third subjective night), and 20 . The dams were also associated in the same cage with their litters until the time of the experiment.

The experimental protocol of the current research was approved by the Committee for Animal Research at Kobe University School of Medicine.

\section{Differential display}

For the differential display study, P2, P10, P20, and P50 animals were used. These animals were killed at ZT4 or 16 under LD conditions. Brains were removed and soaked in ice-cold Tris buffer [Tris- $\mathrm{HCl}$ (50 $\mathrm{mm}), \mathrm{pH}$ 7.5]. Coronal brain slices were cut to $500 \mu \mathrm{m}$ thickness on Brain-Matrix, and the SCN was punched out under a stereomicroscope with a microdissecting needle (inner diameter $500 \mu \mathrm{m}$ ) and quickly homogenized in the Trizol Reagents (Life Technologies BRL, Gaithersburg, MD). As a control, we used a cerebral cortex at P50. Total RNA was prepared from samples using a single-step RNA isolation method (Chomczynski and Sacchi, 1987). mRNA differential display was performed as described previously (Liang and Pardee, 1992; Inokuchi et al., 1996a). Heat-denatured total RNA $(0.5 \mu \mathrm{g})$ was incubated with $300 \mathrm{U}$ of Moloney murine leukemia virus reverse transcriptase (Toyobo) in a $20 \mu \mathrm{l}$ reaction volume for $60 \mathrm{~min}$ at $35^{\circ} \mathrm{C}$ in the presence of $20 \mu \mathrm{M} \mathrm{dNTP}$ and $40 \mathrm{U}$ of ribonuclease inhibitor (Toyobo), using the oligo (dT) primer T12MA, T12MC, T12MG, or T12MT (M, a mixture of A, C, and G) as anchor primer. An aliquot $(0.5 \mu \mathrm{l})$ of the samples was then added to 4.5 $\mu \mathrm{l}$ of PCR solution containing $2 \mu \mathrm{M}$ dNTPs, $5 \mu \mathrm{Ci}\left[\alpha-{ }^{33} \mathrm{P}\right] \mathrm{dATP}(3000$ $\mathrm{Ci} / \mathrm{mmol}$, New England Nuclear), $0.5 \mathrm{U}$ of AmpliTaq polymerase (Perkin-Elmer, Norwalk, CT), $1 \mu \mathrm{M}$ anchor primer (T12MN), and 0.5 $\mu \mathrm{M}$ arbitrary primers. The arbitrary primer (10 mer, $40-60 \%$ GC content) was specifically designed for differential display. PCR parameters were $94^{\circ} \mathrm{C}$ for $3 \mathrm{~min}, 40^{\circ} \mathrm{C}$ for $5 \mathrm{~min}, 72^{\circ} \mathrm{C}$ for $5 \mathrm{~min}$ for the first cycle, $94^{\circ} \mathrm{C}$ for $30 \mathrm{sec}, 40^{\circ} \mathrm{C}$ for $2 \mathrm{~min}, 72^{\circ} \mathrm{C}$ for $30 \mathrm{sec}$ with 35 cycles, then $72^{\circ} \mathrm{C}$ for $5 \mathrm{~min}$ for elongation. Radio-labeled PCR amplification products were analyzed by electrophoresis in denaturing $6 \%$ polyacrylamide gels. Duplicate reactions from identical samples of each RNA preparation were performed and run side by side. Gels were run at $2000 \mathrm{~V}$ for $2.5 \mathrm{hr}$, dried, and exposed directly to XAR-5 film (Kodak) overnight at room temperature. The cDNA bands that showed high in P2 and P10 but low in P20 and P50 without positive signals in the cerebral cortex were cut from the gel and moved to microfuge tubes $(0.5 \mathrm{ml})$. The obtained cDNA fragments were reamplified using the same primer set and PCR conditions used for the differential display reactions. The reamplified DNA fragments were subcloned to pGEM-T Easy vector using the TA-cloning system (Promega, Madison, WI). Using cRNA probes synthesized from PCR products, we performed in situ hybridization of the brain sections including the SCN (Shigeyoshi et al., 1997a). DNAs that expressed strong positive signals in the SCN at developmental stages were selected and sequenced. Six obtained DNA sequences were searched using the BLAST program and the EST and GenBank databases.

One of these genes completely matched the $3^{\prime}$ untranslated region of Lot1 (GenBank accession no. U72620). Because this gene was originally isolated from a rat ovarian surface epithelium cell line, we tried to confirm that the Lot1 gene expressed in the SCN of the brain was the same as that of the cell line. The gene sequence at the translated region was obtained by the hypothalamic cDNA by PCR method. Primers were
5'-GTGGAACAGTGGTTCATCTC-3' (483-502) and 5'-GTCAGATATGACTGACAACC-3' (3113-3132) for the first PCR reaction, and 5'GAAAGTGCGAGAAGCAGAGG-3' (526-545) and 5'-GAAAACGAAGACACCGACAG-3' (3003-3022) for the second reaction.

\section{Northern blot analysis}

Total RNA was prepared from rat peripheral and brain tissue of P50 animals using a single-step RNA isolation method. $\operatorname{Poly}\left(\mathrm{A}^{+}\right) \mathrm{RNA}$ was separated from total RNA using Oligotex-dT30 (Takara). For Northern blot analysis, Poly $\left(\mathrm{A}^{+}\right)$RNA $(2 \mu \mathrm{g})$ was electrophoresed in a $1.2 \%$ agarose gel containing $5.4 \%$ formaldehyde and $1 \times$ MOPS buffer $(1 \times$ MOPS buffer $=20 \mathrm{~mm}$ MOPS, $5 \mathrm{~mm}$ sodium acetate, and $1 \mathrm{~mm}$ EDTA). Transfer of RNA to Hybond-N + nylon transfer membrane (Amersham, Arlington Heights, IL) was performed by capillary blotting with $10 \times$ $\operatorname{SSC}(1 \times \mathrm{SSC}=0.15 \mathrm{M} \mathrm{NaCl}$ and $0.015 \mathrm{~m}$ sodium citrate $)$. After transfer, the nucleic acids were cross-linked to the membrane in a UV cross-linker. For analysis of RNAs, cDNA probes (Lot1; 4697-4955) were labeled with $\left[{ }^{32} \mathrm{P}\right] \mathrm{dCTP}$ (New England Nuclear) by random priming and hybridized in $50 \%$ formamide, $5 \times$ SSC, $5 \times$ Denhardt's solution $(50 \times$ Denhardt's solution $=1 \%$ Ficoll, $1 \%$ polyvinylpyrolidone, and $1 \%$ BSA), $50 \mathrm{~mm}$ phosphate buffer, $\mathrm{pH} 7.5,0.5 \%$ SDS, and $100 \mu \mathrm{g} / \mathrm{ml}$ denatured salmon sperm DNA at $42^{\circ} \mathrm{C}$ for $16 \mathrm{hr}$. After hybridization, filters were washed in $2 \times \mathrm{SSC}$ and $0.1 \%$ SDS for $10 \mathrm{~min}$ at room temperature, twice in the same buffer for $30 \mathrm{~min}$ at $60^{\circ} \mathrm{C}$, and in $0.1 \times \mathrm{SSC}$ and $0.1 \%$ SDS for $1 \mathrm{hr}$ at $50^{\circ} \mathrm{C}$. The washed filters were exposed to XAR-5 film (Kodak) for $12 \mathrm{hr}$ at $-80^{\circ} \mathrm{C}$.

\section{In situ hybridization using radiolabeled probes}

Probes. Vectors containing the PCR product (Lot1; 4697-4955) were linearized with restriction enzymes and used as templates for sense or antisense cRNA probes. Radiolabeled probes for Lot1 were made using ${ }^{35}$ S-dCTP (New England Nuclear) with standard protocols for cRNA synthesis. To check the specificity of hybridization, we synthesized antisense probes of two Lot1 cDNA fragments (954-1599 and 2387-3022) and sense cRNA probe of original PCR products. All three antisense probes produced the same pattern of positive signals (data not shown), and the sense probe produced no positive signals. In all experiments, we used cRNA probe from the original PCR product (Lot1; 4697-4955) for in situ hybridization.

Tissue preparation. Under deep anesthesia by ether, postnatal animals were perfused via the left cardiac ventricle with $0.1 \mathrm{M}$ phosphate buffer (PB) containing $4 \%$ paraformaldehyde. Brains were removed and post-

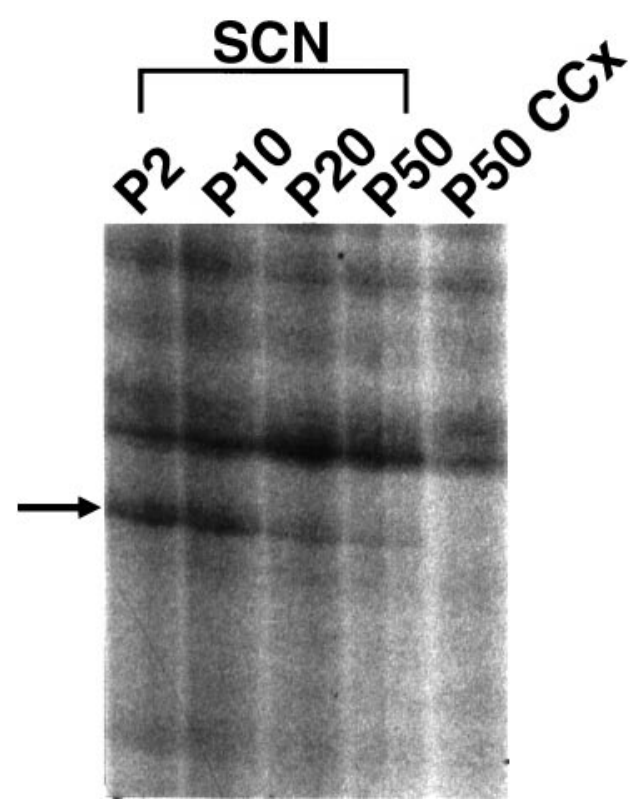

Figure 1. Representative autoradiogram of mRNA differential display with an anchor primer, T12MC, and an arbitrary primer, 5'TGTACGAAAT-3'. Arrow shows cDNA band of Lot1. Samples were collected from SCN at P2, P10, P20, and P50 and from the cerebral cortex at P50. SCN, Suprachiasmatic nucleus; CCX, cerebral cortex. 


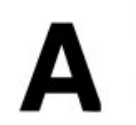

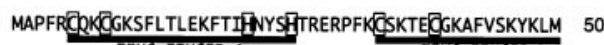

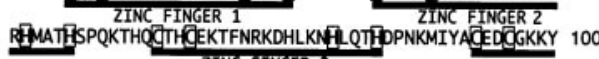

HTMLGYKPPMALASASSGDLTDGVGTLELLSTEVLLDFLKSFAEEKAHHA 150 ZINC FINGER 4 ZINC FINGER 5

PREKKHOGOHCERCFYTRKDVRPFLVWITGCKDFLQOFCAQRFGRKDHLT 200 ZINC FINGER 6 ZINC FINGER?

PPTKKTIFSQELMQESLQAGEYQGGYQPIAPPFQIKADPMPPFQLEMPPES 250

GLDGGLPPEIHGLVLASPEEVPQPMLSMPPMQPMPEQPFTLHPGWPSSP 300 PPIILQEHKYSPVPTSFAPFVSMPMKADLKGFCNMGLFEEFPLQECQSPV 350

KFSQCFEMAKEGFGKVTLPKELLVDAVNIAIPGSLEISSLLGFWQLPPPP 400

PQNGFMNGTIPVGAGEPLPHRITCLAQQQPPPLLPPPPPLPLPEPLPQPQ 450

LPPQFQLQLQPQPQMQPQMQLQPLQLQLPQLLPQLQPEPEPEPEPEEEEE 500

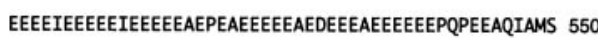

AVNMGQPPLPPTPHVFTAGTNTAILPHFHHAFR

583
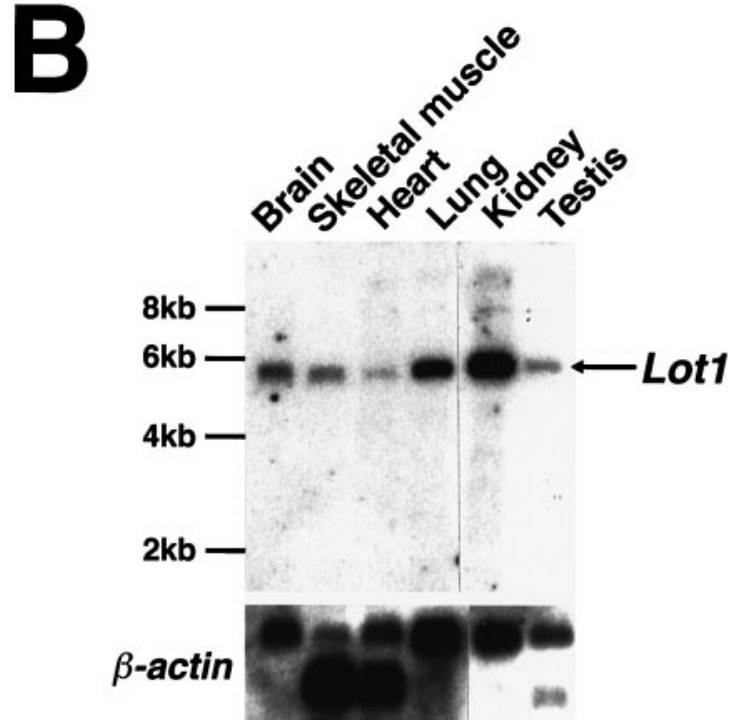

C

ANTISENSE
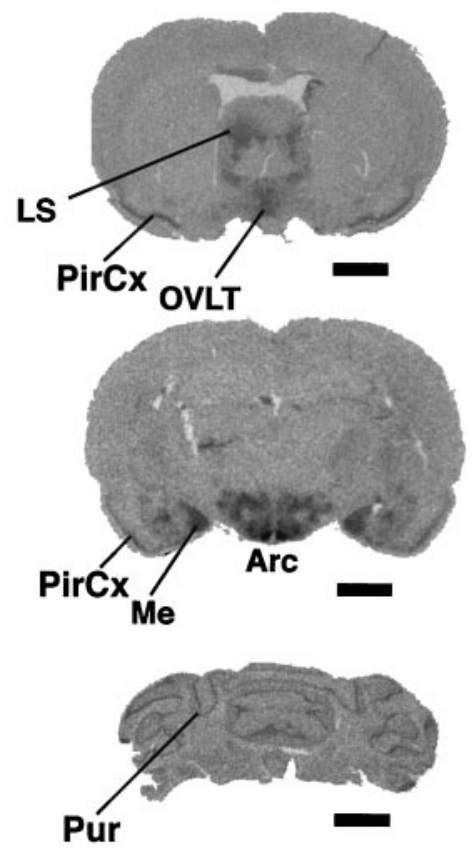

SENSE

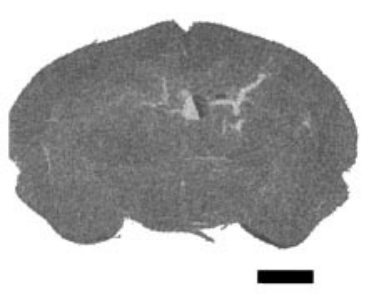

Figure 2. A, Amino acid sequence of LOT1. Zinc-finger motifs are highlighted by bold underlining. Boxes indicate the Cys and His of zinc finger. B, Northern blot analysis of Lot1 in rat tissue RNA. Two micrograms of mRNA in P50 rat tissues were loaded on each lane. $\beta$-actin served as a loading control. $C$, In situ hybridization using antisense probe and sense probe in P50 rat brain. Photomicrographs were taken using Bio-max film (Kodak). Arc, Arcuate hypothalamic nucleus; $L S$, lateral septal nucleus; $M e$, medial amygdaloid nucleus; $O V L T$, organum vasculosum lamina terminalis; $P$ irC $C$, piriform cortex; Pur, Purkinje cell layer. Scale bars, $2 \mathrm{~mm}$.

fixed in the same fixative for $12 \mathrm{hr}$ at $4^{\circ} \mathrm{C}$. For the preparation of fetal animals, pregnant dams were deeply anesthetized with ether, and fetuses were removed and immersed in the same fixative for $24 \mathrm{hr}$ at $4^{\circ} \mathrm{C}$. Fixed brains were then transferred into $20 \%$ sucrose in PB for $72 \mathrm{hr}$. Frontal sections $(40 \mu \mathrm{m}$ in thickness for anatomical localization study and $50 \mu \mathrm{m}$ in thickness for quantitative hybridization study) were made using a cryostat and processed for the free-floating in situ hybridization method as described previously (Ban et al., 1997; Shigeyoshi et al., 1997b). For the quantitative analysis, we collected all sections from the rostral end of the SCN to the retrochiasmatic area. We also thaw-mounted frontal and sagittal sections ( $40 \mu \mathrm{m}$ in thickness) on silane-coated microscope slides (Okamura et al., 1990) and processed them for in situ hybridization.

Hybridization. Free-floating and thaw-mounted sections were processed following the same protocols of prehybridization, hybridization, and posthybridization washes. The thaw-mounted and free-floating sections were treated with $0.1 \mathrm{mg} / \mathrm{ml}$ proteinase K (Sigma, St. Louis, MO), $10 \mathrm{~mm}$ Tris buffer, $\mathrm{pH} 7.4$, and $10 \mathrm{~mm}$ EDTA for $5 \mathrm{~min}$ at $37^{\circ} \mathrm{C}$, then with $4 \%$ paraformaldehyde in $0.1 \mathrm{M} \mathrm{PB}$ for $5 \mathrm{~min}$. Because free-floating sections from developing rats are fragile, the proteinase $\mathrm{K}$ treatment was omitted in free-floating sections obtained from rats younger than P10. Then sections from rats of all ages were treated with $0.25 \%$ acetic anhydride in $0.1 \mathrm{M}$ triethanolamine for $10 \mathrm{~min}$. The sections were then incubated in hybridization buffer (60\% formamide, $10 \%$ dextran sulfate,
$1 \times$ Denhardt's solution, 20 mm Tris-HCl, $\mathrm{pH}$ 8.0, 5 mм EDTA, $\mathrm{pH}$ 8.0, $0.3 \mathrm{M} \mathrm{NaCl}, 10 \mathrm{~mm}$ NaPB, pH $8.0,0.2 \% \mathrm{~N}$-laurylsarcosine, and $500 \mathrm{mg} / \mathrm{ml}$ yeast tRNA) containing the ${ }^{35} \mathrm{~S}$-dCTP-labeled cRNA probe for $12 \mathrm{hr}$ at $60^{\circ} \mathrm{C}$. After hybridization, these sections were rinsed in $20 \times \mathrm{SSC} / 50 \%$ formamide for $15 \mathrm{~min}$ twice at $60^{\circ} \mathrm{C}$, and the sections were treated with a solution containing $20 \mathrm{mg} / \mathrm{ml}$ RNase A, $10 \mathrm{~mm}$ Tris-HCl, $\mathrm{pH} 8.0,1 \mathrm{~mm}$ EDTA, and $0.5 \mathrm{M} \mathrm{NaCl}$ for $30 \mathrm{~min}$ at $37^{\circ} \mathrm{C}$. The sections were rinsed further in $2 \times \mathrm{SSC} / 50 \%$ formamide for $15 \mathrm{~min}$ twice at $60^{\circ} \mathrm{C}$ and in $0.5 \times$ SSC for $30 \mathrm{~min}$ at $60^{\circ} \mathrm{C}$.

Sections for free-floating in situ hybridization were mounted onto gelatin-coated microscope slides. All sections were air-dried and dehydrated through a graded alcohol series. The slides were exposed to BioMax film (Kodak) at $4^{\circ} \mathrm{C}$ for $3 \mathrm{~d}$. The films were developed using a Kodak D19 developer for $5 \mathrm{~min}$ at $20^{\circ} \mathrm{C}$. The slides were dipped in Kodak NTB2 nuclear track emulsion (dilution 1:1 distilled water), developed after 2 weeks, and counterstained by Nissl staining (cresyl violet).

Quantitative in situ hybridization. Serial frontal sections $(50 \mu \mathrm{m}$ in thickness) of rats were made from the rostral end to the caudal end of the SCN using a cryostat. In this experiment, we used P10 rats to obtain a signal intensity sufficient for analyzing the diurnal rhythm of Lot1 mRNA signals in the SCN. Quantification of mRNA has been described (Okamura et al., 1995; Ban et al., 1997). The radioactivity of each section of the BioMax film (Kodak) was analyzed using a microcomputer inter- 


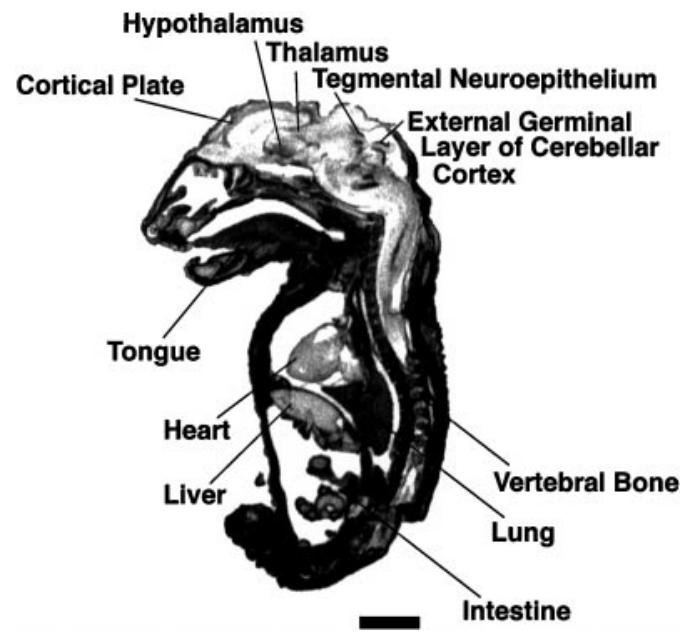

Figure 3. Expression of Lot1 mRNA in fetal rat (E20) detected by in situ hybridization using antisense probe. Sense controls performed in the adjacent sections showed no signals. Scale bar, $2 \mathrm{~mm}$.

faced to an image analyzing system (MCID, Imaging Research) after conversion into the relative optical density using ${ }^{14} \mathrm{C}$-acrylic standards (Amersham). The rostralmost to the caudalmost of the SCN (13 sections per rat) were then summed; the sum was considered a measure of the amount of Lot1 mRNA in this region. Statistical analyses of the data were made using one-way ANOVA followed by Scheffé's multiple comparisons.

Developmental change of the relative amount of Lot 1 mRNA in the SCN was also examined by film autoradiographic image at E20, P1, P3, $\mathrm{P} 5, \mathrm{P} 7, \mathrm{P} 10, \mathrm{P} 20$, and $\mathrm{P} 50$ rats. The value at P3 is adjusted to 100 .

\section{RESULTS}

\section{cDNA cloning using mRNA differential display in rat SCN}

We used mRNA differential display (Liang and Pardee, 1992; Inokuchi et al., 1996b) to isolate cDNA clones that are differentially expressed in the developing SCN of the rat brain. Eighty combinations of primer sets made of four anchor primers and a group of 20 arbitrary 10-mers were used for screening. By this method, seven independent cDNAs were isolated in which mRNA levels were markedly modulated in the SCN at ZT4 during early neonatal periods. When a primer pair of T12MC and an arbitrary primer 5'-TGTACGAAAT-3' was used, we detected PCR products of $259 \mathrm{bp}$. Figure 1 shows that signals of the PCR product at $\mathrm{P} 2$ and $\mathrm{P} 10$ were strong, but they were weak at P20 and very weak at P50. DNA sequence analysis of the PCR product using the BLAST program and GenBank databases revealed that the sequence of obtained PCR products matched 259 bp (46974955) of the 3' untranslated region of Lot1 cDNA (Abdollahi et al., 1997), which has seven zinc-finger motifs of the $\mathrm{C}_{2} \mathrm{H}_{2}$ type, as well as proline-rich, glutamine-rich, and glutamic acid-rich areas (GenBank accession no. U72620). We cloned the translated region of Lot1 from the hypothalamic cDNA using PCR. Among the coding sequences (548-2299), the following DNA sequences from hypothalamic cDNA were different from the reported sequence: $\mathrm{C} \rightarrow \mathrm{T}(916,1836), \mathrm{T} \rightarrow \mathrm{C}(1816,2263), \mathrm{A} \rightarrow \mathrm{G}(2053$, $2071,2089,2095,2117)$, and $\mathrm{A} \rightarrow \mathrm{T}$ (2188). However, the translated amino acid sequence of Lot1 from the hypothalamic cDNA was identical to the reported one (Fig. 2A).

Tissue distribution of Lot1 mRNA in adult rats: Northern blot analysis and in situ hybridization

First, we examined Lot1 expression in the rat body and brain before examining its expression in the developing SCN. To de-
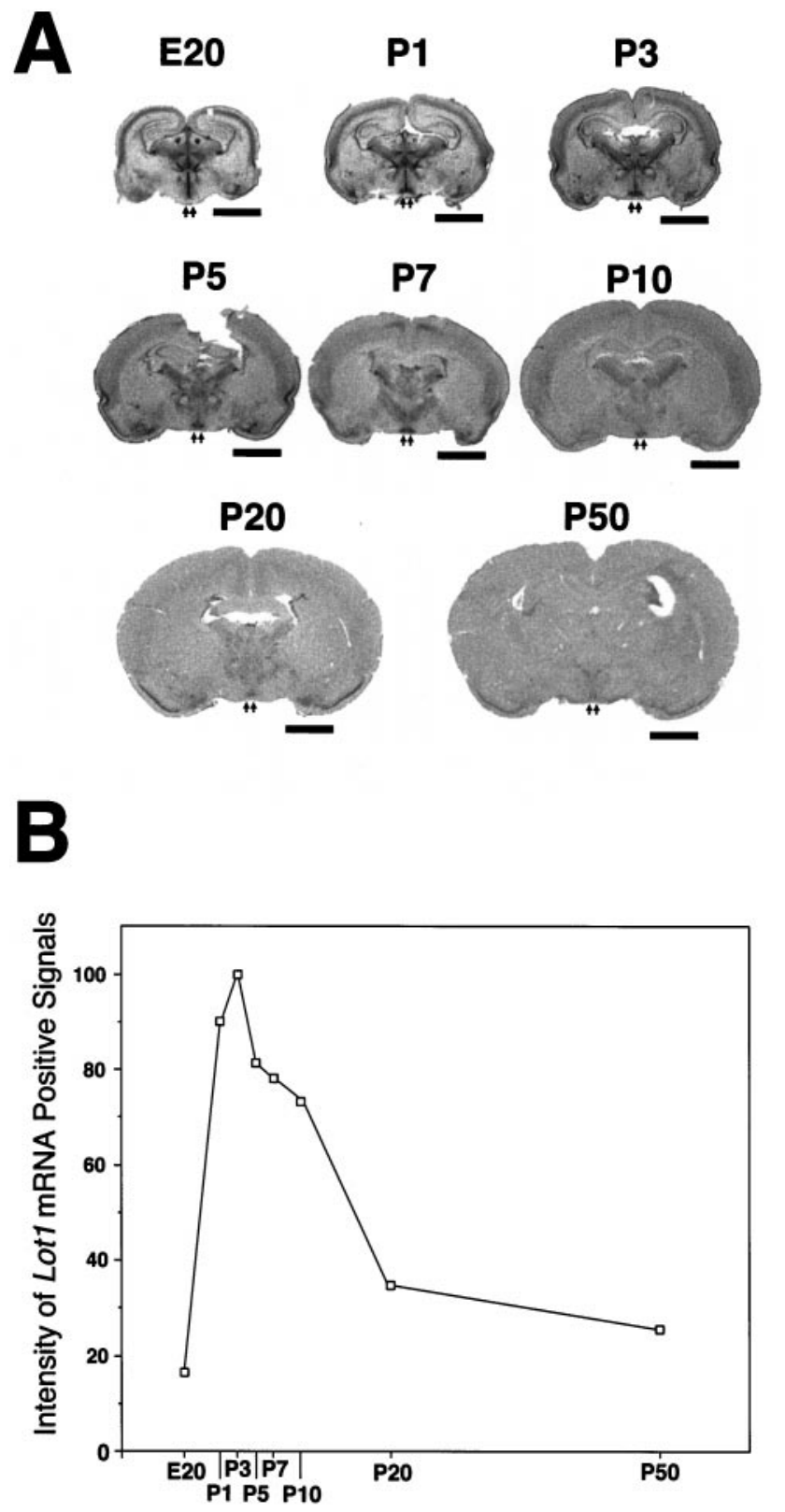

Figure 4. Expression of Lot1 mRNA in the developing SCN. A, Film autoradiographic image of in situ hybridization of Lot $1 \mathrm{mRNA}$ in the SCN of E20, P1, P3, P5, P7, P10, P20, and P50 rats. Scale bars, 2 mm. B, Developmental change of the relative amount of Lot1 mRNA in the SCN. The value at P3 is adjusted to 100 .

termine the tissue distribution of Lot1, we performed Northern blot analysis using obtained PCR products (4697-4955) of the 3' untranslated region of Lot1 cDNA as a probe. A transcript of $\sim 5.5 \mathrm{~kb}$ was detected in all rat tissue, including brain, skeletal muscle, heart, lung, kidney, and testis (Fig. 2B). The amount of Lot 1 mRNA was highest in the kidney, high in the lung, moderate in the brain, testis, and skeletal muscle, and low in the heart.

Expression of Lot1 mRNA in the adult rat brain was examined by in situ hybridization. We found high levels of signals in the hypothalamic arcuate nucleus and moderate levels in the piriform cortex, lateral septum, medial amygdaloid nucleus, and the Purkinje cells of the cerebellar cortex (Fig. 2C). No signals were detected using the sense probe. 

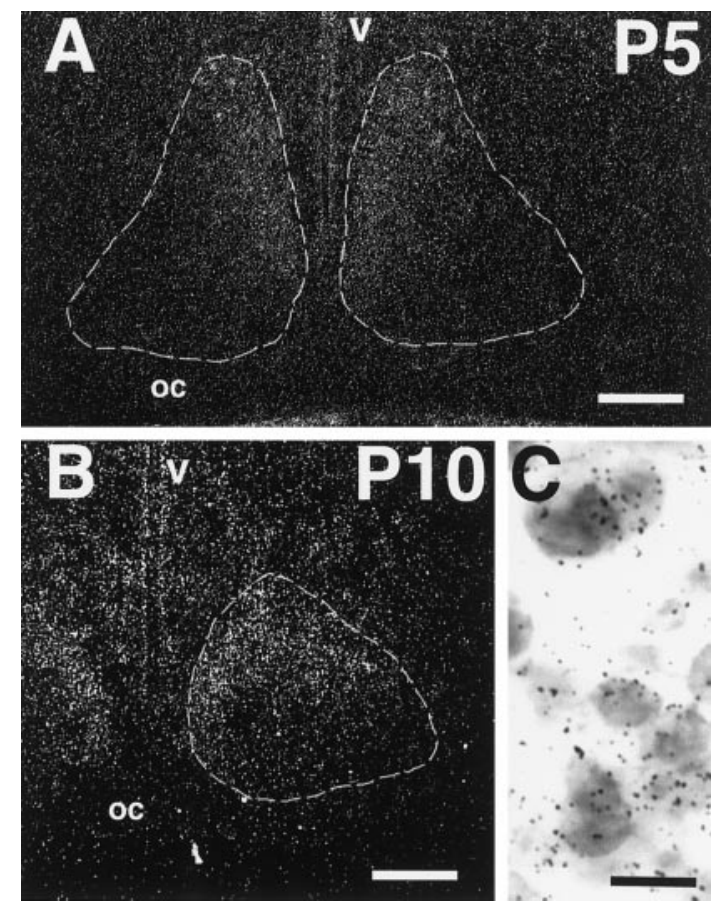

Figure 5. Dark-field emulsion image of Lot1 mRNA in P5 $(A)$ and P10 $(B, C)$ rat SCN. SCN is outlined by broken lines in $A$ and $B$. $C$, Bright-field high-power photomicrograph of the dorsomedial SCN in $B$. oc, Optic chiasma; $v$, third ventricle. Scale bars: $A, B, 100 \mu \mathrm{m} ; C, 10 \mu \mathrm{m}$.

\section{The expression of Lot1 mRNA in developing rats}

The expression of Lot1 mRNA was also examined during the perinatal age (E18 and E20) by in situ hybridization using the antisense cRNA probe (Lot1; 4697-4955). At both E18 and E20, we found clear positive signals in most organs in the rat; high in the lung, tongue, intestine, and vertebral bone but weak in the heart and liver (Fig. 3). Using the sense probe, we found no signals in any of these structures by our present hybridization condition (data not shown).

In the brain, moderate levels of positive signals were detected in the external germinal layer of the cerebellar cortex, the tegmental neuroepithelium, the hypothalamus, and the cortical plate of the cerebral cortex (Fig. 3). The positive signals detected in the developing cerebral cortex disappeared at the adult stage.

\section{The expression of Lot1 mRNA in the developing and adult SCN}

To observe the developmental modification of the expression of Lot1 mRNA in the SCN, we performed in situ hybridization using Lot1 cRNA probes with coronal sections of the brain at E20, P1, P3, P5, P7, P10, P20, and P50 (Fig. 4A). Lot1 mRNA signals of the SCN were very weakly expressed at E20. At P1, when the animals were just born, very intense signals appeared in the SCN. This high level of signals increased to the highest level at P3, and then gradually decreased but was still high until P10 (Fig. 4B). However, the level of signals at P10 was much higher than that at P20 and P50 (adult rats).

To delineate the localization of positive signals in the SCN, we performed emulsion autoradiogram. At both P5 and P10, Lot1 mRNA signals were found in the dorsomedial part of the suprachiasmatic nucleus (DMSCN) but not in the ventrolateral part of the suprachiasmatic nucleus (VLSCN) (Fig. 5). DMSCN neurons expressed abundant Lot1 mRNA signals (Fig. 5C).

\section{Rhythm of Lot1 mRNA expression in the SCN at P10}

To explore the daily expression of Lot1 mRNA at the developmental stage, we compared the Lot 1 signals at $4 \mathrm{hr}$ intervals in LD and DD conditions at P10. In both LD and DD conditions, sections at ZT/CT4 (4 hr after dawn or subjective dawn) showed the highest signals. We quantified Lot1 mRNA in the SCN by the quantitative in situ hybridization method (Fig. 6). The peaktrough rhythm profiles were similar in both LD and DD conditions. In the LD condition, Lot1 mRNA showed a clear diurnal rhythm, forming a peak at ZT4 and a trough at ZT0. The increase from ZT0 to ZT4 was very sharp, but the decline was very gradual. The level of the peak was $\sim 1$. 7 -fold higher than that of the trough. In the DD condition, Lot1 mRNA showed a clear circadian rhythm, forming a peak at CT4 and a trough at CT20, with the same peak/trough ratio as in LD.

\section{DISCUSSION}

In this study, we identified a putative transcription factor, Lot1, expressed in the SCN only at specific developmental stages. The results of the first screening by gel-loading of amplified genes were consistent with those of in situ hybridization, which suggests that our screening procedure is effective in cloning genes differentially expressed in the SCN. Many researchers have applied the differential display method to rat $\mathrm{SCN}$, retina, and pineal body to identify genes expressed in a circadian manner, but only some preliminary reports are available (Gauer et al., 1995; Chong et al., 1996). The only success was the trial of Green and Besharse (1996b), who identified a specifically night-expressed photoreceptor mRNA nocturnin in Xenopus retina (Green and Besharse, 1996a).

The specific structural features of LOT1, the existence of zinc-finger motifs in their putative protein sequence, indicate that LOT1 is a DNA-binding protein that may play a role as a transcriptional regulator. Originally, Lot1 was isolated from rat ovarian surface epithelial cell lines by the differential display method (Abdollahi et al., 1997). The deduced amino acid sequence from the open reading frame contains seven zinc-finger motifs of the $\mathrm{C}_{2} \mathrm{H}_{2}$ type, which belongs to the $\mathrm{C}_{2} \mathrm{H}_{2}$ class of zinc-finger proteins, typified by the Xenopus leaves TIIIF (Pelham and Brown, 1980; Miller et al., 1985) and mouse Zif268 (Christy et al., 1988). Some zinc-finger proteins, such as Zic1, contribute to development of the brain (Aruga et al., 1998). Similarly, abundant Lot1 mRNA in the developmental brain and poor expression in adults suggest that Lot1 may contribute to the process of CNS development. During the prenatal period, many regions of the brain express a large amount of Lot $1 \mathrm{mRNA}$, and this strong expression continues until P10, but from then to the adult stage, brain signals are markedly suppressed. In the SCN, transient but strong expression of Lot 1 was observed in the early postnatal days (P1-P10), and later, the signal intensity rapidly decreased to a very faint level during the adult stage.

Early postnatal days with strong expression of Lot 1 in the SCN correspond to the period when each SCN neuron attains unity of each oscillating neuron by mutual innervation. Moore and Bernstein (1989) reported that synaptogenesis of SCN occurs after birth, and in particular it occurs predominantly during the early postnatal days until P10, when Lot1 is highly expressed. These synapses may be derived from the mutual connection of intrinsic neurons of the SCN, because innervation from external origins is reached later (Takatsuji et al., 1995). Retinal terminals reach to the SCN during the late gestational period (Bunt et al., 1983), but Güldner (1978) reported that optic nerve terminals containing 


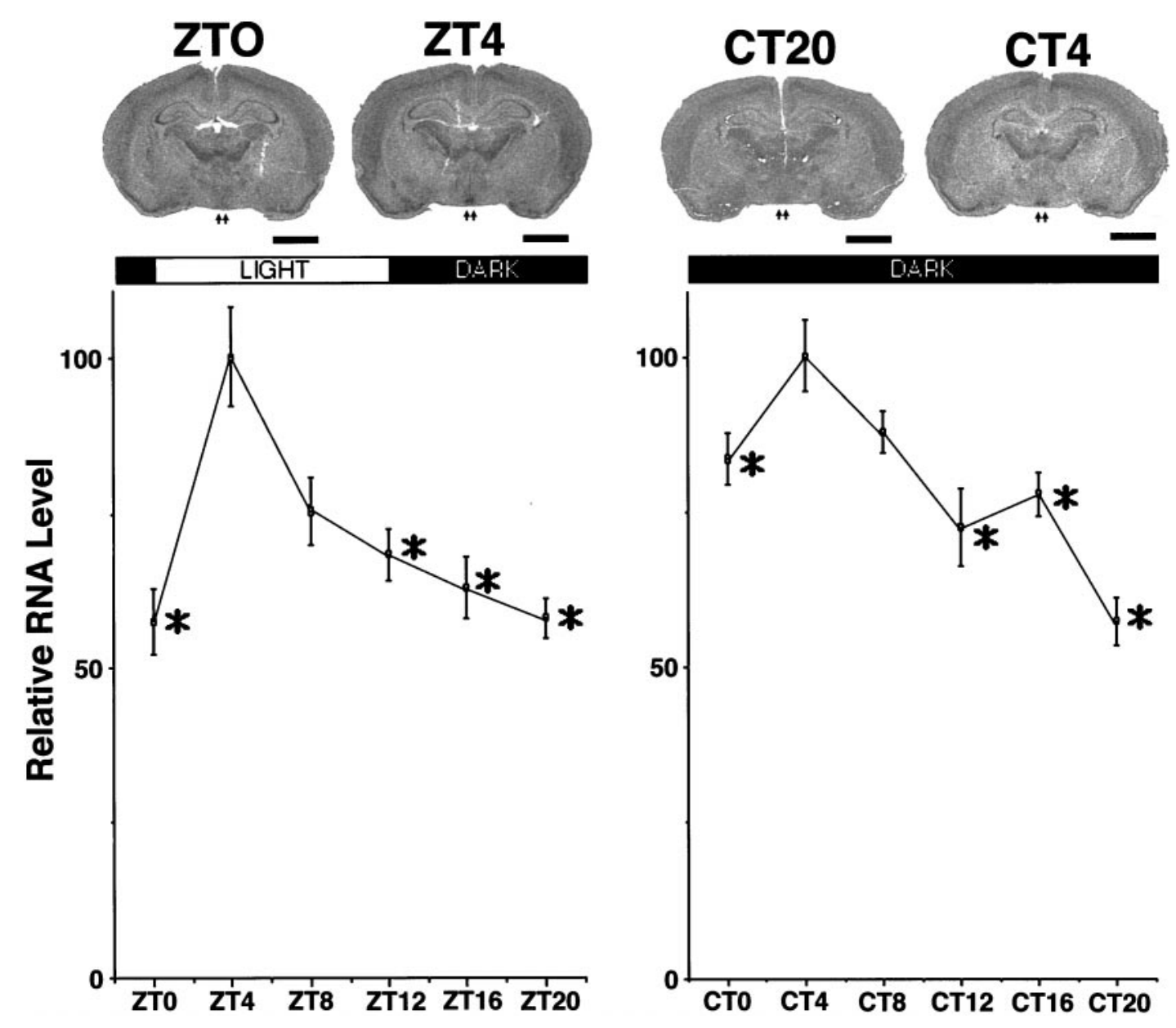

Figure 6. Diurnal and circadian profiles of Lot1 mRNA levels in the SCN of P10 rats. Quantitative in situ hybridization analysis of Lot1 mRNA in the P10 rat brain under $12 \mathrm{hr} \mathrm{LD}$ and total darkness (DD) is shown. Values are means $\pm \operatorname{SEM}(n=7) .{ }^{*} p<0.05$, compared with the value at ZT4 or CT4 (ANOVA). Representative sections are shown in top panels; SCN is indicated by arrows. Scale bars, $2 \mathrm{~mm}$.

characteristic tubular mitochondria make synapses first at P9, and those synapses increase and mature from P17 to P27. Raphe serotonergic and geniculohypothalamic neuropeptide Y innervations most vigorously increase between P10 and P20 (Takatsuji et al., 1995). Thus the strong timing correlation of mutual intrinsic synaptic connection and the expression of Lot1 suggest that the essential function of Lot1 is in coupling among SCN neurons. During the period of Lot 1 expression, the amplitude of circadian rhythm of firing rate of SCN neurons greatly increases (Shibata and Moore, 1987), although only a weak day-night difference in electrical activity was observed at the late gestational period.

Because Lot1 mRNA expression is confined to the DM part of the SCN from the beginning to the adult stage, Lot1 may contribute to the development and differentiation of DMSCN neurons. In the rat, cytoarchitectonic subdivision of DM and VL regions is evident at least from P6 (Moore, 1991). In adult, neurons in the DMSCN are small, with scant cytoplasm, and well packed compared with VLSCN, with more widely spaced neurons and more cytoplasm. In addition to the cytoarchitectonic difference, the chemical and physiological characteristics of neurons are different between DMSCN and VLSCN. Most neurons of the DMSCN express arginine-vasopressin (AVP) and aromatic L-amino acid decarboxylase with endogenous oscillation, whereas neurons in the VLSCN produce VIP and gastrinreleasing peptide with light-dependent expression. Ontogeneti- cally, AVP appears first in the DMSCN at P2 and gradually increases to the adult level at P10 (De Vries et al., 1981), and this maturation period mimics the period of expression of Lot 1 in the SCN. Together with the finding that endogenous c-fos expression is enhanced in the dorsomedial part during the first 10 postnatal days (Joyce and Barr, 1995), Lot1 expression might help maturation of DMSCN neurons as a putative transcription factor.

Interestingly, mouse Lot 1 is isolated in the expression cloning study independently from the study of rat Lot1 cloning, and from its ability to induce apoptosis and cell cycle arrest, the mouse Lot1 gene is called Zac1 (a zinc-finger protein that regulates apoptosis and cell cycle arrest) (Spengler et al., 1997). In the developing SCN, neuronal cell death was observed in the first postnatal days (Moore, 1991). Recently Müller and Torrealba (1998) performed quantitative analysis of cell death in the Syrian hamster and found that $40 \%$ cell loss occurred in the SCN between $\mathrm{P} 2$ and $\mathrm{P} 6$, just before the arrival of retinal fibers. The timing of expression of the apoptotic-inducing factor Lot1 and cell death seemed similar, but we must be cautious about this conclusion because there is a difference of several days in development among the two species. However, the apoptotic role of Lot1 gene expression at the very strict time point of the developing SCN may be important because the reorganization of neurons by apoptosis is an inevitable step for the differentiation of neurons in many nervous systems. 
Although the circadian clock in adults is entrained by the light-dark cycle, in the fetal and neonatal animals environmental light-dark cycles cannot be monitored directly; thus the nonphotic entrainment system by maternal cues is very important in these animals (Takahashi et al., 1989; Hastings et al., 1998). Cross-fostering studies have shown that maternal cues exert a powerful effect on the neonatal clock, with newborn litters adopting the circadian phase of their foster mother if fostered within the first weeks of life (Takahashi et al., 1989). Because the underlying mechanisms of maternal entrainment are not fully understood, the postnatal expression of Lot 1 in dorsomedial SCN is possible to associate with the postnatal entrainment of the SCN by maternal-derived cues and the development of nonphotic entrainment of the SCN (Weaver and Reppert, 1995; Hastings et al., 1998; Duffield et al., 1999).

The Lot 1 mRNA transcription in the SCN might be controlled by a circadian clock. The SCN exhibits circadian oscillation of Lot1 mRNA levels, forming a peak during the (subjective) day and a trough during the (subjective) night in both LD and DD conditions at P10. The circadian profile of this expression pattern mimics that of chemical substances expressed in DMSCN neurons: AVP formed a peak during the subjective day and a trough during the subjective night at both mRNA and peptide levels (Tominaga et al., 1992; Cagampang and Inouye, 1994). The daytime peak and nighttime trough patterns are similar to the expression pattern of rPer1 and rPer2 (Yan et al., 1999) and suggest that all of these bioactive substances expressed in the DMSCN are under the control of mammalian putative clock period genes. For AVP, Jin et al. (1999) recently demonstrated that CLOCK-BMAL1 heterodimers bind to the E-box of the 3' flanking sequence of AVP promoter and accelerate transcription, and mPER1 negatively regulates its gene transcription. The similarities between the profiles of circadian mRNA fluctuation in AVP and Lot1 suggest that Lot1 is also under a similar regulatory mechanism and directly controlled by circadian clock genes.

In conclusion, we detected a putative transcription factor, Lot1, expressed in neurons of developing DMSCN by the differential mRNA display method. Lot 1 mRNA is expressed very strongly in the limited phase of development between P1 and P10, which is identical to the period of massive synaptogenesis that occurs among intrinsic neurons. This putative transcription factor is expressed under the control of circadian rhythm and may contribute to the maturation of autonomous oscillation of oscillator cells with little direct influence of light stimulation (Shigeyoshi et al., 1997b; Yan et al., 1999).

\section{REFERENCES}

Abdollahi A, Godwin AK, Miller PD, Getts LA, Schultz DC, Taguchi T, Testa JR, Hamilton TC (1997) Identification of a gene containing zinc-finger motifs based on lost expression in malignantly transformed rat ovarian surface epithelial cells. Cancer Res 57:2029-2034.

Altman J, Bayer SA (1978) Development of the diencephalon in the rat II. Autoradiographic study of the time of origin and settling pattern of neurons in the hypothalamus. J Comp Neurol 182:945-972.

Aruga J, Minowa O, Yaginuma H, Kuno J, Nagai T, Noda T, Mikoshiba $\mathrm{K}$ (1998) Mouse Zic1 is involved in cerebellar development. J Neurosci 18:284-293.

Ban Y, Shigeyoshi Y, Okamura H (1997) Development of circadian VIP rhythm in the rat suprachiasmatic nucleus. J Neurosci 17:3920-3931.

Bunt SM, Lund RD, Land PW (1983) Prenatal development of the optic projection in albino and Hooded rats. Dev Brain Res 6:149-168.

Cagampang FRA, Inouye ST (1994) Circadian variation of argininevasopressin messenger RNA in the rat suprachiasmatic nucleus. Mol Brain Res 24:179-184.

Chomczynski P, Sacchi N (1987) Single-step method of RNA isolation by acid guanidinium thiocyanate-phenol-chloroform extraction. Anal Biochem 162:156-159.

Chong NWS, Cagampang FRA, Coen CW, Campbell IC, Powell JF (1996) Rapid identification of novel genes expressed in a circadian manner in rat suprachiasmatic nuclei. NeuroReport 7:1199-1203.

Christy BA, Lau LF, Nathans D (1988) A gene activated in mouse 3T3 cells by serum growth factors encodes a protein with "zinc finger" sequences. Proc Natl Acad Sci USA 85:7857-7861.

De Vries GJ, Buijs RM, Swaab DF (1981) Ontogeny of the vasopressinergic neurons of the suprachiasmatic nucleus and their extrahypothalamic projections in the rat brain: presence of a sex difference in the lateral septum. Brain Res 218:67-78.

Duffield GE, McNulty S, Ebling FJP (1999) Anatomical and functional characterisation of a dopaminergic system in the suprachiasmatic nucleus of the neonatal siberian hamster. J Comp Neurol 40:873-896.

Dunlap JC (1999) Molecular bases for circadian clocks. Cell 96:271-290.

Gauer F, Kedzierski W, Craft CM (1995) Identification of circadian gene expression in the rat pineal gland and retina by mRNA differential display. Neurosci Lett 187:69-73.

Green CB, Besharse JC (1996a) Identification of a novel vertebrate circadian clock-regulated gene encoding the protein nocturnin. Proc Natl Acad Sci USA 93:14884-14888.

Green CB, Besharse JC (1996b) Use of a high stringency differential display screen for identification of retinal mRNAs that are regulated by circadian clock. Mol Brain Res 37:157-165.

Güldner FH (1978) Synapses of optic nerve afferents in the rat suprachiasmatic nucleus. I. Identification, qualitative description, development and distribution. Cell Tissue Res 194:17-35.

Hastings MH, Duffield GE, Smith EJD, Maywood ES, Ebling FJP (1998) Entrainment of the circadian system of mammals by non-photic cues. Chronobiol Int 15:425-445.

Ifft JD (1972) An autoradiographic study of the time of final division of neurons in rat hypothalamic nuclei. J Comp Neurol 144:193-204.

Inokuchi K, Kato A, Hiraia K, Hishinuma F, Inoue M, Ozawa F (1996a) Increase in activin bA mRNA in rat hippocampus during long-term potentiation. FEBS Lett 382:48-52.

Inokuchi K, Maruyama A, Ozawa F (1996b) mRNA differential display reveals krox-20 as a neural plasticity-regulated gene in the rat hippocampus. Biochem Biophys Res Commun 221:430-436.

Inouye S-IT, Kawamura H (1979) Persistence of circadian rhythmicity in a hypothalamic "island" containing the suprachiasmatic nucleus. Proc Natl Acad Sci USA 76:5962-5966.

Jin X, Shearman LP, Weaver DR, Zylka MJ, de Vries GJ, Reppert SM (1999) A molecular mechanism regulating rhythmic output from the suprachiasmatic nucleus. Cell 96:57-68.

Joyce MP, Barr GA (1995) Ontogeny of the Fos protein-like immunoreactivity in the suprachiasmatic nucleus. Synapse 21:54-59.

Liang P, Pardee AB (1992) Differential display of eukaryotic messenger RNA by means of the polymerase chain reaction. Science 257:967-971.

Miller J, McLachlan AD, Klug A (1985) Repetitive zinc-binding domains in the protein transcription factor IIIA from Xenopus oocytes. EMBO J 4:1609-1614.

Moore RY (1973) Retinohypothalamic projection in mammals: a comparative study. Brain Res 49:403-409.

Moore RY (1991) Development of the suprachiasmatic nucleus. In: Suprachiasmatic nucleus. The mind's clock (Klein DC, Moore RY, Reppert SM, eds), pp 391-404. New York: Oxford UP.

Moore RY, Bernstein ME (1989) Synaptogenesis in the rat suprachiasmatic nucleus demonstrated by electron microscopy and synapsin 1 immunoreactivity. J Neurosci 9:2151-2162.

Müller C, Torrealba F (1998) Postnatal development of neuron number and connections in the suprachiasmatic nucleus of the hamster. Dev Brain Res 110:203-213.

Okamura H, Abitbol A, Julien J-F, Dumas S, Bérod A, Geffard M, Kitahama K, Bobillier P, Mallet J, Wiklund L (1990) Neurons containing messenger RNA encoding glutamic acid decarboxylase (GAD) in rat hypothalamus demonstrated by in situ hybridization, with special emphasis on cell groups in medial preoptic area and dorsomedial hypothalamic nucleus. Neuroscience 39:675-699.

Okamura H, Kawakami F, Tamada Y, Geffard M, Nishiwaki T, Ibata Y, Inouye S-IT (1995) Circadian change of VIP mRNA in the rat suprachiasmatic nucleus following p-chlorophenylalanine (PCPA) treatment in constant darkness. Mol Brain Res 29:358-364.

Pagotto U, Arzberger T, Ciani E, Lezoualch F, Pilon C, Journot L, Spengler D, Stalla GK (1999) Inhibition of Zac1, a new gene differ- 
entially expressed in the anterior pituitary, increases cell proliferation. Endocrinology 140:987-996.

Pelham HRB, Brown DD (1980) A specific transcription factor that can bind either the 5S RNA gene or 5S RNA. Proc Natl Acad Sci USA 77:4170-4174.

Reppert SM, Schwartz WJ (1984) The suprachiasmatic nuclei of the fetal rat: characterization of a functional circadian clock using ${ }^{14} \mathrm{C}$-labeled deoxyglucose. J Neurosci 4:1677-1682.

Shibata S, Moore RY (1987) Development of neuronal activity in the rat suprachiasmatic nucleus. Dev Brain Res 34:311-315.

Shibata S, Moore RY (1988) Development of fetal circadian rhythm after disruption of the maternal circadian rhythm. Dev Brain Res 41:313-317.

Shigeyoshi Y, Maebayashi Y, Okamura H (1997a) Co-localization of preprosomatostatin mRNA and preprotachykinin A mRNA in neurons of the rat suprachiasmatic nucleus. Mol Brain Res 48:159-163.

Shigeyoshi Y, Taguchi K, Yamamoto S, Takekida S, Yan L, Tei H, Moriya T, Shibata S, Loros JJ, Dunlap JC, Okamura H (1997b) Lightinduced resetting of a mammalian circadian clock is associated with rapid induction of the mPer1 transcript. Cell 91:1043-1053.

Spengler D, Villalba M, Hoffman A, Pantaloni C, Houssami S, Bockaert J, Journot L (1997) Regulation of apoptosis and cell cycle arrest by Zac1, a novel zinc finger protein expressed in the pituitary gland and the brain. EMBO J 16:2814-2825.
Takahashi K, Ohi K, Shimoda K, Tamada N, Hayashi S (1989) Postnatal maternal entrainment of circadian rhythms. In: Research in perinatal medicine IX: development of circadian rhythmicity and photopediodism in mammals (Reppert SM, ed), pp 67-82. New York: Perinatology Press.

Takatsuji K, Oyamada H, Tohyama M (1995) Postnatal development of substance $\mathrm{P}$-, neuropeptide $\mathrm{Y}$ - and serotonin-containing fibers in the rat suprachiasmatic nucleus in relation to development of retinohypothalamic projection. Dev Brain Res 84:261-270.

Tominaga K, Shinohara K, Otori Y, Fukuhara C, Inoue S-IT (1992) Circadian rhythms of vasopressin content in the suprachiasmatic nucleus of the rat. NeuroReport 3:809-812.

Varrault A, Ciani E, Apiou F, Bilanges B, Hoffmann A, Pantaloni C, Bockaert J, Spengler D, Journot L (1998) hZaC encodes a zinc finger protein with antiproliferative properties and maps to a chromosomal region frequently lost in cancer. Proc Natl Acad Sci USA 95:8835-8840.

Weaver DR, Reppert SM (1989) Periodic feeding of SCN-lesioned pregnant rats entrains the fetal biological clock. Dev Brain Res 46:291-296.

Weaver DR, Reppert SM (1995) Definition of the developmental transition from dopaminergic to photic regulation of c-fos gene expression in the rat suprachiasmatic nucleus. Mol Brain Res 33:136-148.

Yan L, Takekida S, Shigeyoshi Y, Okamura H (1999) Per1 and Per2 gene expression in the rat suprachiasmatic nucleus: circadian profile and the compartment-specific response to light. Neuroscience 94:141-150. 